\title{
Kelayakan Berita dalam Proses Gatekeeping di Lembaga Penyiaran Publik TVRI Jakarta (Studi Kasus Program Soft News "Semangat Pagi Indonesia" pada 22 Mei 2019)
}

\author{
Nelson, Roswita Oktavianti \\ nelson.915150166@stu.untar.ac.id,roswitao@fikomuntar.ac.id \\ Fakultas Ilmu Komunikasi Universitas Tarumanagara
}

\begin{abstract}
Media is a reference for the community as knowledge of the world around them. The community is "thirsty" for information so that the speed of updates is the main priority of today's mass media. However, news quality is often not a concern. TVRI Jakarta Public Broadcasting Institution (LPP) is a reference to spread accurate and factual news. This study was intended to find out how the news feasibility in the process of gatekeeping at LPP TVRI Jakarta. Researchers use the theory of gatekeeping, a worthy element of news in stateowned television stations. The researcher interviewed Editor-in-Chief of LPP TVRI Jakarta, Agil Samal, and the News Producer of "Semangat Pagi Indonesia" Zainul Muttaqin regarding the process of gatekeeping in determining the news feasibility of the "Semangat Pagi Indonesia" program on May 22 2019. At that time riot demonstrators at the BRIMOB dorm, who rejected the results of the KPU's decision to win the number one candidate pair, Joko Widodo. In processing data, researchers use a case study method. The results showed that the coverage in LPP TVRI Jakarta was in accordance with the theory of gatekeeping. But there are still flaws in the news feasibility at LPP TVRI Jakarta. Weaknesses in the aspect of news balance. When reporting on the demonstration, TVRI was not objective because it only took from one perspective, the government.
\end{abstract}

Keywords: Worth the News, Soft News, Gatekeeping

\begin{abstract}
Abstrak
Media menjadi acuan masyarakat sebagai pengetahuan akan dunia di sekitar mereka. Masyarakat "haus" akan informasi sehingga menjadikan kecepatan update sebagai prioritas utama media massa saat ini. Namun, kualitas berita seringkali tidak menjadi perhatian. Lembaga Penyiaran Publik (LPP) TVRI Jakarta menjadi acuan untuk menyebarkan berita yang akurat dan faktual. Penelitian ini dimaksudkan untuk mengetahui bagaimana kelayakan berita dalam proses gatekeeping di LPP TVRI Jakarta. Peneliti menggunakan teori gatekeeping, unsur layak berita dalam stasiun televisi milik pemerintah. Teknik pengumpulan data diperoleh melalui wawancara dengan redaksi mengenai proses gatekeeping dalam menentukan kelayakan berita. Studi kasus dilakukan pada program "Semangat Pagi Indonesia" edisi 22 Mei 2019. Pada saat itu, terjadi kerusuhan pendemo di asrama BRIMOB, yang menolak hasil keputusan KPU yang memenangkan pasangan calon nomor urut satu yaitu Joko Widodo. Hasil penelitian menunjukkan bahwa pemberitaan di LPP TVRI Jakarta sudah sesuai dengan teori gatekeeping. Namun masih ada kekurangan dalam kelayakan berita di LPP TVRI Jakarta. Kekurangannya dalam aspek keseimbangan berita. Pada saat memberitakan aksi demonstrasi tersebut, TVRI tidak obyektif karena hanya mengambil opini dari satu sudut pandang yakni pemerintah.
\end{abstract}


Kata Kunci: Kelayakan Berita, Soft News, Gatekeeping

\section{Pendahuluan}

Media massa telah menjadi salah satu media penyampai pesan atau informasi kepada khalayak. Pada umumnya, ada tiga jenis media di dunia, yaitu televisi, radio, dan media cetak. Televisi memberikan manfaat terutama dalam hal hiburan dan informasi. Hal ini karena televisi menyediakan fasilitas audio visual yang ampuh dalam menyampaikan pesan demokratif. Bagi masyarakat Indonesia, televisi merupakan media yang memberikan siaran mendidik, menghibur dan memberikan informasi, kepada khalayak dengan penyelenggaraan siaran dalam suatu lingkaran industri (Djamal \& Farhruddin, 2013).

Gatekeeper berfungsi sebagai orang yang ikut menambah atau mengurangi, menyederhanakan, mengemas agar semua informasi yang disebarkan lebih mudah dipahami. Gatekeeper juga berfungsi untuk menginterprestasikan pesan, menganalisis, menambah data, dan mengurangi pesan-pesannya. Intinya, gatekeeper merupakan pihak yang ikut menentukan pengemasan sebuah pesan dari media massa (Nurudin, 2009:31). Pada penelitian ini, penulis memilih Lembaga Penyiaran Publik TVRI Jakarta untuk menggambarkan gatekeeping suatu berita.

Proses gatekeeping dilakukan dengan standarisasi yang berbeda-beda. Meskipun demikian, para gatekeeper memiliki prinsip yang sama mengenai hal-hal yang menjadi ketertarikan penonton dan sesuai dengan aturan sosial budaya. Gatekeeper secara tidak langsung telah menentukan nilai-nilai berita atau news value dalam proses pemilihan berita. Galtung dan Ruge (McQuail, 2010:310), menjabarkan tiga nilai berita yang mempengaruhi pemilihan berita.

a. Organisasi (organizational)

Terorganisirnya suatu berita, subjektif mengenai peristiwa dan berita yang sesuai dengan waktu dan susunan pemilihan dan proses transmisi ulang. Hal ini mendukung peristiwa yang terjadi di dekat fasilitas peliputan dengan ketersediaan narasumber yang terpercaya.

b. Keterkaitan aliran (genre-related)

Pemberitaan yang sesuai dengan ekspektasi audiens dan dapat dengan segera digantikan dengan istilah yang mudah diinterpretasikan.

c. Sosial budaya (socio-cultural)

Dasar proses pemilihan berita asing yang difokuskan pada individu dan melibatkan ketertarikan dalam kaum elit dan peristiwa negatif, dramatis, dan kekerasan.

Berita merupakan hasil dari proses kerja jurnalistik yang mengelola peristiwa melalui media massa. Berita merupakan sesuatu yang telah diolah melalui bahasa dan teknik tertentu dari peristiwa yang merupakan kejadian aktual objektif. Berita adalah informasi aktual tentang fakta-fakta dan opini yang menarik perhatian orang (Kusumanigrat dan Kusumanigrat, 2009:40). Berikut adalah unsur-unsur layak berita:

\section{a. Berita harus akurat}

Berita yang akurat adalah berita yang kecermatannya terhadap angka, nama, usia dan tanggal serta disiplin diri untuk senantiasa teliti atas keterangan dan fakta yang ditemuinya. Akurat berarti benar dalam memberikan kesan umum, benar dalam sudut pandang pemberitaan yang dicapai oleh penyajian detail-detail fakta dan oleh tekanan yang diberikan fakta-faktanya. 


\section{b. Berita harus berimbang \\ Wartawan harus memberitakan apa yang sesungguhnya terjadi. \\ c. Berita harus objektif}

Pemberitaan berdasarkan fakta, tidak dipotong dan diubah oleh kepentingan subjektif.

\section{d. Berita harus ringkas dan jelas}

Wartawan harus mengembangkan ketentuan-ketentuan yang disepakati tentang bentuk dan cara membuat berita. Penulisan berita yang efektif adalah berita yang ringkas, terarah, tepat, menggugah. Inilah kandungan-kandungan kualitas yang harus dikejar oleh setiap penulis.

\section{e. Berita harus hangat}

Berita adalah "news" dalam bahasa inggris. Kata "news" bisa juga diartikan "baru". Jadi berita harus terbaru dan hangat (Kusumanigrat dan Kusumanigrat, 2009:57).

TVRI adalah lembaga penyiaran yang membawa nama negara mengandung arti bahwa dengan nama tersebut siarannya mementingkan kepentingan negara. Melalui Undang-Undang Republik Indonesia Nomor 32 Tahun 2002 tentang Penyiaran, TVRI ditetapkan sebagai Lembaga Penyiaran Publik yang berbentuk badan hukum yang didirikan oleh negara.

Peraturan Pemerintah RI Nomor 13 Tahun 2005 menetapkan bahwa tugas TVRI adalah memberikan pelayanan informasi, pendidikan dan hiburan yang sehat, kontrol dan perekat sosial, serta melestarikan budaya bangsa untuk kepentingan seluruh lapisan masyarakat melalui penyelenggaraan penyiaran televisi yang menjangkau seluruh wilayah Negara Kesatuan Republik Indonesia.

Semangat Pagi Indonesia merupakan sebuah acara televisi yang ditayangkan oleh TVRI. Acara ini ditayangkan setiap hari pukul 06:00-08:00 WIB. Acara ini pertama kali dimulai pada tahun 2014. Berisi acara yang berhubungan dengan berita, jalan-jalan, dan olahraga serta mengudara selama dua jam. Mulai 1 Maret 2015, Semangat Pagi Nusantara berubah nama menjadi Semangat Pagi Indonesia. Program ini sekarang juga menghadirkan Band Indonesia yaitu Starway Band dan Starway Music Community. Acara ini merupakan reinkarnasi dari Selamat Pagi Nusantara yang pernah tayang pada tahun 2010. Acara ini juga memakai laporan dari TVRI Daerah (www.tvri.co.id).

Penelitian terdahulu dilakukan oleh Yoedtadi, dkk, mengenai upaya redaksi media dalam menjaga obyektivitas di pemberitaan Pilkada DKI Jakarta. Hasil dari penelitian tersebut adalah redaksi media bersikap adil dengan memberikan durasi berita yang sama untuk setiap pasangan calon (paslon) gubernur DKI Jakarta, lalu mereka menempatkan urutan berita para paslon Gubernur DKI Jakarta sesuai urutan nomor kandidat paslon yang ditetapkan Komisi Pemilihan Umum, lalu menjaga frekuensi berita paslon Gubernur DKI Jakarta secara tetap, dengan menugaskan tiga tim liputan untuk menempel setiap hari dengan ketiga paslon tersebut, dan selalu menjaga secara adil kemunculan ketiga paslon Gubernur DKI Jakarta di setiap segmen khusus Pilkada DKI Jakarta.

Peneliti mengangkat topik, "Kelayakan Berita dalam proses Gatekeeping di Lembaga Penyiaran Publik TVRI Jakarta (Studi Kasus program Soft News pada 'Semangat Pagi Indonesia' pada 22 Mei 2019)'. 


\section{Metode Penelitian}

Penelitian ini bersifat kualitatif deskriptif. Penelitian deskriptif dimaksudkan untuk pengukuran yang cermat terhadap fenomena sosial tertentu, misalnya perceraian, pengangguran, keadaan gizi, preferensi terhadap politik tertentu dan lainlain (Singarimbun, 1989:4). Penelitian ini menggunakan metode studi kasus. Penelitian studi kasus akan kurang kedalamannya apabila hanya difokuskan pada saat tertentu saja. Studi kasus yang baik harus dilakukan secara langsung dalam kehidupan sebenarnya dari kasus yang diselidiki. Studi kasus yang dilakukan pada penelitian ini adalah program soft news "Semangat Pagi Indonesia" pada 22 Mei 2019 di LPP TVRI. TVRI merupakan subjek penelitian ini, dan obyek dari penelitian ini adalah proses gatekeeping.

Peneliti menggunakan hasil wawancara dengan Pimpinan Redaksi Agil Samal, dan produser berita Zainul Muttaqin dari Lembaga Penyiaran Publik TVRI Jakarta sebagai sumber data primer. Penelitian ini menggunakan sumber data sekunder seperti sumber buku, majalah ilmiah, dan dokumen-dokumen dari pihak yang terkait mengenai pembentukan berita pada acara "Semangat Pagi Indonesia" 22 Mei 2019 Lembaga Penyiaran Publik TVRI Jakarta.

Teknik triangulasi digunakan sebagai bentuk keabsahan data. Triangulasi dalam pengujian kredibilitas diartikan sebagai pengecekan data dari berbagai sumber dengan berbagai waktu. Dengan demikian terdapat triangulasi sumber, triangulasi teknik pengumpulan data, dan waktu (Sugiyono, 2007:273). Pada penelitian ini, penulis membuktikan keabsahan data dengan triangulasi sumber dengan mewawancarai salah satu penonton TVRI yaitu Stevanus Wikarta. Penulis akan menanyakan mengenai indikator-indikator di dalam unsur layak berita.

\section{Hasil Temuan dan Diskusi}

Penulis mewawancarai Pimpinan Redaksi Agil Samal dan produser berita Zainul Muttaqin dari Lembaga Penyiaran Publik TVRI Jakarta mengenai proses gatekeeping dan kelayakan berita pada program "Semangat Pagi Indonesia" tanggal 22 Mei 2019. Alasan penulis mengambil pemberitaan program "Semangat Pagi Indonesia" pada 22 Mei 2019 adalah karena pada tanggal tersebut LPP TVRI menayangkan tentang kerusuhan para pendemo di asrama BRIMOB, pasca pengumuman KPU mengenai pengesahan pasangan calon presiden, Joko Widodo.

Berita tersebut diteliti dari segi kelayakan berita dan proses gatekeeping media televisi nasional LPP TVRI. Berdasarkan temuan, ada beberapa pembahasan mengenai kelayakan berita dalam proses gatekeeping di LPP TVRI Jakarta yaitu tentang nilai berita yang mendukung berjalannya proses gatekeeping (organisasi, keterkaitan aliran, dan sosial budaya) dan juga tentang unsur layak berita (berita harus akurat, berita harus berimbang, berita harus obyektif, berita harus ringkas dan jelas, dan berita harus hangat). 
Penulis menjabarkan beberapa hasil diskusi mengenai nilai berita yang sebagai acuan berjalannya proses gatekeeping (McQuail, 2010).

\section{a. Organisasi}

TVRI melakukan prosedur yang sesuai dengan teori tersebut. Hanya saja ada perbedaan argumen tentang narasumber yang dipilih pada berita acara "Semangat Pagi Indonesia 22 Mei 2019". TVRI telah membentuk berita dengan terorganisir, dan menentukan kriteria berita dalam acara "Semangat Pagi Indonesia" yakni menggunakan bahasa yang bersahabat tetapi tidak melupakan fakta dan keakuratan informasi.

"Memproses berita yang sebenarnya tidak mengurangi konten, karena untuk morning show dibuat lebih ringan. Jadi berita-beritanya yang kita sampaikan tetap sama sesuai liputan, tetapi penyajiannya berbeda." (Agil Samal)

\section{b. Keterkaitan Aliran}

Pemberitaan di TVRI sudah cukup memuaskan ekspektasi masyarakat karena disebutkan bahwa TVRI khususnya di dalam acara "Semangat Pagi Indonesia" sudah mempunyai segmen yang membantu masyarakat untuk dapat berkontribusi menjadi jurnalis tanpa keterikatan. Bahkan TVRI menyiarkan berita yang viral di media sosial dimana termasuk permintaan dari masyarakat yang tentu saja berita tersebut sudah melewati proses verifikasi viral.

"Kita justru punya segmen tersendiri di acara Semangat Pagi yang menayangkan hal-hal yang viral di media sosial. Kami juga ada proses verifikasi viral sebelum menayangkan hal tersebut. Misalkan tadi pagi, kami menerima hashtag \#HBDJokowi dari masyarakat dan kita tayangkan juga.” (Agil Samal)

\section{c. Sosial dan Budaya}

TVRI memilih berita ringan untuk dibawakan di acara "Semangat Pagi Indonesia" karena acara tersebut bertujuan untuk menemani masyarakat dalam melakukan aktivitas pagi. TVRI juga akan menayangkan berita yang berat jika berita tersebut sudah menjadi perbincangan dunia.

"Biasanya ringan, di acara Semangat Pagi Indonesia. Ada dua berita asing yang dipilih. Pertama, ada hard news, yang pada hari itu menjadi perbincangan dunia. Kedua itu, ada yang ringan sekali, seperti yang inspiratif. Hal yang ringan-ringan untuk menemani orang sarapan itu lebih banyak ditayangkan daripada yang hard news." (Agil Samal)

Berikutnya penulis akan menjabarkan beberapa hasil diskusi mengenai unsur layak berita (Kusumanigrat dan Kusumanigrat, 2009):

\section{Berita harus Akurat}

TVRI sudah melakukan proses produksi berita dengan baik sesuai standar yang telah dilakukan dan ditentukan oleh stasiun televisi lainnya. Proses pembentukan berita yang dilakukan oleh TVRI sudah melewati banyak tahap yang harus ditandatangani oleh pemimpin readaksi dan pemimpin lainnya dalam melakukan penyiaran berita. Hal ini membuktikan gatekeeping TVRI sudah terbukti sesuai dengan teori. TVRI juga mengikuti peraturan UUD 1945 tentang kode etik jurnalistik yang ditentukan oleh KPI. TVRI termasuk media yang paling rendah melakukan pelanggaran dan mendapat teguran dari KPI. 
"Tentunya berdasarkan yang dikeluarkan KPI, P3SPS (Pedoman Perilaku Penyiaran Standar Program Siaran). Tentunya, hal-hal yang mambawa pengaruh buruk, dan bahkan anak-anak dibawah umur yang melakukan pelanggaran harus disensor. Kita sangat taat terhadap peraturan, bahkan di KPI kita termasuk stasiun yang paling rendah melakukan pelanggaran dan mendapatkan teguran. Pengetahuan ini sudah dikuasai oleh semua yang bekerja disini, jadi saat live pun kameramen sudah tahu apa yang boleh diambil dan yang tidak boleh diambil" (Agil Samal).

"Proses produksinya sama seperti proses berita lainnya, dimulai dari news gathering, hasil liputannya disusun, dikumpulkan, di-edit, dan lain-lain seperti proses pemotongan, proses kompilasi, dan di cross check sebelum ditayangkan.” (Agil Samal)

\section{Berita harus Berimbang}

TVRI tetap berimbang atau cover both sides dalam pemberitaan, tetapi TVRI akan melakukan pengambilan satu sudut pandang apabila kasus tersebut sudah bertentangan dengan kebijakan pemerintah. Dalam hal ini, TVRI kurang berimbang karena TVRI tidak memberitakan apa yang sesungguhnya terjadi. Kondisi tersebut tidak tepat karena media harus netral dan harus memberitakan sesuai apa yang terjadi di lapangan.

"TVRI dinilai sebagai media televisi yang masih dapat dipercaya, di dalam gatekeeping itu banyak prosesnya sebelum ditayangkan. Kalau ternyata berita tersebut tidak berimbang, maka TVRI harus mencari dahulu narasumber lain untuk mengimbangkan berita tersebut, jika berita tersebut sudah tidak tertolong, maka berita tersebut tidak boleh tayang." (Agil Samal)

\section{Berita harus Obyektif}

TVRI objektif dalam beberapa hal. Terkadang TVRI juga subjektif terhadap lembaga-lembaga negara. Dapat dilihat dari hasil wawancara diatas bahwa TVRI menerima permintaan pemberitaan dari lembaga-lembaga negara.

"Pemberitaan di TVRI pernah diarahkan untuk kepentingan-kepentingan nasional" (Agil Samal)

\section{Berita harus Ringkas dan Jelas}

TVRI kurang menerapkan hal ini, karena TVRI bahkan pernah menayangkan berita dengan durasi selama satu setengah jam tanpa henti (non stop). Sebaliknya, terdapat berita dengan durasi sangat pendek. Hal ini dikarenakan penyiaran berita di TVRI tidak mengacu terhadap durasi, tetapi mengacu terhadap fakta yang didapatkan.

"Tetap menggunakan standar jurnalistik, namun tergantung informasi yang didapat." (Zainul Muttaqin)

\section{Berita harus Hangat}

Berita yang hangat tidak ditentukan oleh media itu sendiri, tetapi ditentukan oleh khalayak. Di dalam pemberitaan TVRI, mereka tetap menyiarkan berita walaupun sudah "basi", selama hal itu belum mereka siarkan ke publik.

"Selama berita tersebut belum diberitakan walaupun sudah seminggu, tetap kami akan tayangkan. Hangatnya suatu berita itu hanya penonton yang bisa menilai. Kami tidak pernah menunda berita, selama berita tersebut belum disiarkan, kami tetap akan siarkan ke publik.” (Agil Samal) 
Dalam mengukur keabsahan data, peneliti melakukan wawancara dengan Stevanus Wikarta, sebagai salah satu penonton berita "Semangat Pagi Indonesia edisi 22 Mei 2019". Menurut sumber, kebenaran dalam berita tersebut telah terverifikasi. TVRI tidak menggunakan narasumber dalam berita dan TVRI hanya mengambil sudut pandang dari para aparat dan korban dari kerusuhan. Sementara tidak ada narasumber dari pihak massa pendemo.

\section{Simpulan}

Berdasarkan unsur layak berita, berita yang berimbang menurut LPP TVRI Jakarta adalah cover both sides, namun terkadang tetap memihak negara, apabila peristiwa yang terjadi bertentangan dengan kebijakan pemerintah. Selain itu, TVRI juga terbukti akurat dalam membentuk berita karena TVRI menerapkan berita yang teliti terhadap setiap angka, nama, tanggal dan usia serta disiplin diri untuk senantiasa melakukan periksa ulang atas keterangan dan fakta yang ditemuinya. Lalu, kehangatan berita tidak ditentukan oleh media itu sendiri, tetapi ditentukan oleh khalayak. Di dalam pemberitaan TVRI, mereka tetap menyiarkan berita walaupun sudah lama atau "basi", selama hal itu belum mereka siarkan kepada publik.

Selanjutnya, dari segi nilai berita, berita di TVRI Jakarta sudah cukup terorganisir karena proses produksi dalam TVRI Jakarta juga melewati gatekeeping yang ketat dalam membentuk suatu berita. TVRI Jakarta melakukan proses verifikasi yang cukup panjang dalam pembentukan berita.

TVRI khususnya di dalam acara "Semangat Pagi Indonesia" sudah mempunyai segmen yang membantu masyarakat untuk dapat berkontribusi menjadi jurnalis tanpa keterikatan. Bahkan, TVRI menyiarkan berita yang viral di media sosial, termasuk permintaan dari masyarakat. Namun berita tersebut sudah melewati proses verifikasi viral.

TVRI memilih berita ringan untuk dibawakan di acara "Semangat Pagi Indonesia" karena acara tersebut bertujuan untuk menemani masyarakat dalam melakukan aktvitas pagi. TVRI juga akan menayangkan berita yang berat jika berita tersebut sudah menjadi perbincangan dunia.

\section{Ucapan Terima Kasih}

Penulis berterimakasih kepada para narasumber karena telah memberi kesempatan dan memberi informasi kepada penulis selama proses pengumpulan data untuk penelitian ini. Penulis juga mengucapkan terima kasih yang sebesar-besarnya kepada dosen pembimbing, teman-teman, serta Fakultas Ilmu Komunikasi Universitas Tarumanagara.

\section{Daftar Pustaka}

Hidajanto Djamal \& Andi Fachruddin. (2013). Dasar-Dasar Penyiaran. Makassar: Kencana.

Kusumaningrat, Hikmat dan Purnama Kusumaningrat. (2009). Jurnalistik: Teori dan Praktik, Bandung: PT Remaja Rosdakarya.

McQuail. (2010). Mass Communication Theory 6th Edition. London: Sage Publication. 
Vol. 3, No. 1, Juli 2019, Hal 220-227

Singarimbun, Masri dan Sofian Effendi. (1989). Metode Penelitian Survey. LP3ES. Jakarta.

Yoedtadi, Muhammad Gafar. (2017). Upaya Redaksi Televisi Menjaga Objektivitas dalam Pemberitaan Pilkada DKI Jakarta. Jakarta: Untar Press. 